УДК 94:342.25:36(47+57)“1917"

И.П. Павлова

DOI: 10.36718/2500-1825-2020-1-145-155

\title{
ПРАВО СОБСТВЕННОСТИ НА ЗЕМЛЮ В УСЛОВИЯХ РЕВОЛЮЦИИ 1917 Г. В РОССИИ
}

I.P. Pavlova

\section{THE PROPERTY RIGHT TO LAND DURING THE RUSSIAN REVOLUTION OF 1917}

Представлен анализ правовых аспектов в деятельности Временного правительства, Юридического совещания, Главного земельного комитета, идеи юристов-цивилистов по вопросу о собственности на землю. Выявлено, что первые мероприятия Временного правительства отражали стремление сохранить право частной собственности на землю. Поворот произошел после начала массовых самозахватов владельческих земель крестьянами. После июльского кризиса юристы и руководители страны сосредоточились на вопросе возмездности при изъятии земель у землевладельцев, считали необходимым оставить в действии институты передачи права собственности на землю, которые существовали до революции (дарственные, купчие крепости, выкупы родовых имуществ, передача прав по закладным, право пожизненного владения, сервитуты и др.). Постепенно стал вырабатываться подход по легализации происходящих стихийных переделов для постепенного возвращения в русло законности, возникла идея ограничения срока переходного периода при перераспределении прав на владения землей. В течение всего периода до октября 1917 г. властные структуры и правоведы осуждали самовольные захваты земли. Отказа от идеи необходимости возмещения имущественного ущерба при потере прав на землю среди правоведов руководящего блока в условиях революции так и не произошло. Тесно связан с правом собственности был вопрос о сделках по земле, которые были запрещены окончательно в июле 1917 г. В целом статья иллюстрирует непреодолимые противоречия двух правопредставлений о владении землей: частнособственнического и крестьянского, обычно-правового, в основе которого лежали традиционые представления о ничейном, общем характере земли как имущества.

Ключевые слова: частная собственность на землю, аграрный вопрос, Временное правительство, земельные комитеты, Юридическое совещание. 
The analysis of legal aspects of the activity of Russian Provisional Government, Judicial consultation, Chief land committee, concepts of specialists in civil law with regard to property right to land was submitted. It was revealed that the first actions of Provisional government reflected the aspiration to keep the right of private property for the land. The situation changed after the beginning of mass self-occupations of possessory lands by peasants. After the July crisis the lawyers and Russian authorities concentrated their attention on the issue of compensation upon land withdrawal from land owners, it was believed necessary to retain the mechanisms of transfer of property right to land, which were valid before the Revolution (gift deeds, bills of sale, redemption of ancestral estates, transfer of mortgage bond rights, right of possession for life, easements, etc.). The approach to legalization of spontaneous rearrangements started to be developed gradually aimed at stepwise return to legitimacy and to constraints of transition period of reallocation of property rights to land. During the entire period till October, 1917 the authorities and lawyers condemned unauthorized occupancy of lands. Giving up the concept of obligatory compensation in the case of loss of right to land during the Revolution did not happen. The issue of transactions with land, which were finally prohibited in July, 1917 was closely related with the property right. In general, the article illustrates insurmountable contradictions of two legal concepts about possession of land: private ownership and peasants' mentality, unofficial law, based on conventional wisdom about uncontested common belonging of land as property. In general the study illustrates insurmountable contradictions of two legal concepts about possession of land: private ownership and peasants' mentality, unofficial law, based on conventional wisdom about uncontested common belonging of land as property.

Key words: private property of land, agrarian issue, Provisional Government, land committees, Judicial consultation.

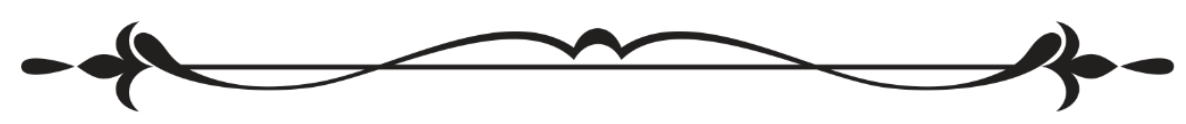

Цель исследования - анализ правового поля периода революции 1917 г. по вопросу о собственности на землю. Источниками стали решения и проекты Временного правительства, Юридического совещания, Временного совета Российской республики (Предпарламента), работы специалистов по праву и экономике исследуемого периода и др.

Общепризнано в истории поземельных отношений России существование правового дуализма: двух правовых систем - позитивного права (на базе рецепции норм западного, в основе своей римского права) и права обычного, составлявшего основу правосознания большей части населения Российской империи, - крестьянского [1, с. 169], которые можно свести к тому, что земля принадлежит «всем и никому», «ничья», 


\section{Социально-экономический и әуманитарный журнал Красноярского ГАУ. 2020. № 1}

«мирская», «Божья», и которые базировались на общинном, подворном владении и отрицании права собственности на землю.

Университетская цивилистическая мысль в отношении земли в XIX - начале XX в. развивалась в направлении обеспечения полной частной собственности на землю. В этом же направлении строилась земельная политика государства. Это видно на примере унификации правовых способов передачи владельческих прав на землю. В конце XIX в. постепенно был ликвидирован институт чиншевого права, исчезало посессионное право. В ходе реализации столыпинских законов закреплялись частные наделы, юридически оформлялись выходы из общин. В проекте Гражданского уложения, книге III «Вотчинное право» фиксировалось право частной собственности на землю как основное право на недвижимость [2, с. 410-411].

После февральских событий во властных кругах превалировала идея сохранения права частной земельной собственности, то есть существовавшего правового положения, до решения земельного вопроса Учредительным собранием. 19 марта Временное правительство приняло постановление «О подготовке материалов по земельному вопросу», в котором говорилось, что земельный вопрос, в том числе вопрос о распределении земельной собственности, должен быть решен путем закона, принятого народным представительством [3, с. 10]. В ведомственной телеграмме заместителя министра внутренних дел С.Д. Урусова комиссарам Временного правительства от 3 апреля подчеркивалось, что необходимо ограждать «свободы каждого владельца распоряжаться своею землею» [4, с. 451]. Продолжалось организационно-техническое обеспечение передачи прав собственности на землю. Это выражалось в решении правительства от 20 марта о печатании в определенных газетах объявлений о продаже недвижимого имущества Дворянским земельным банком и другими кредитными учреждениями [3, с. 283]. Разрешались пожертвования землями на благотворительные цели [3, с. 386] (то есть легально изменялись собственники земельных участков). Правительство в условиях весеннего сева (постановление «Об охране посевов», 11 апреля) гарантировало возмещение убытков от земельных беспорядков частным владельцам и крестьянам [3, с. 157].

Поворот от защиты «священного и неприкосновенного» права частной собственности в решениях власти и выступлениях юристов и политиков кадетского круга начал происходить в условиях посевных работ, сопровождавшихся массовыми самовольными захватами земель помещиков и отходников. В том же постановлении «Об охране посевов» вводилось право принудительной передачи пустующих земель в арендное пользование другим владельцам или земельным комитетам [3, с. 157]. Созданные земельные комитеты должны были разрешать через посреднические и примирительные камеры по типу третейских судов споры и недоразумения в области земельных и сельских отношений «согласно 
действующим законам». В Воззвании Временного правительства по земельному вопросу от 21 апреля признавалась необходимость установления «нового земельного строя» решением Учредительного собрания [3, с. 429-430]. Понятие «нового земельного строя» не разъяснялось.

После июльского кризиса обновленное Временное правительство заявило, что в основу земельной реформы будет положена «мысль о переходе земли в руки трудящихся», что целью является «полная ликвидация разрушительной и дезорганизующей деревню прежней землеустроительной политики». Но вопрос о собственности на землю не должен был «предрешаться» до созыва Учредительного собрания, а самовольные захваты осуждались как «противоречащие принципу общегосударственного плана будущей земельной реформы» [5, с. 5-6]. Сами члены Временного правительства разных составов - земельные собственники оказались в роли пострадавших от крестьянских разгромов и потрав. В Курской губернии - в июле 1917 г. разгромили усадьбу М.И. Терещенко, в октябре в Нижегородской губернии - Н.М. Кишкина и др. [6, с. 66].

Первым правовым ограничением частной собственности стал законопроект о временной приостановке и запрещении сделок по земле. Несогласие с таким ограничением стало, по мнению исследователей, причиной правительственного кризиса и основным мотивом отставки первого министра-председателя кн. Г.Е. Львова, считавшего неприемлемым «поставить Учредительное собрание перед фактом уже разрешенного вопроса о земле» [1, с. 333].

Весной-летом образовывались союзы земельных собственников. 20 мая в Москве собралось учредительное собрание обновленного Всероссийского союза земельных собственников, участниками которого стали около трехсот землевладельцев из 31-й губернии. Целью Союза была объявлена «защита земельной собственности и объединение деятельности лиц, признающих право частной собственности основой существования государства» через пропаганду, защиту прав собственности в суде [7]. Во главе Союза стоял А.В. Кривошеин. Землевладельцы возражали против ограничения земельных сделок. Они направляли свои возмущения по поводу посягательства на право частной собственности на землю во Временное правительство. Помещик М. Боборыкин писал М.В. Родзянко в письме от 9 июня: «Я - помещик, и в моей голове не укладывается, чтобы я лишился своей земли, да еще для самой невероятной цели: для опыта социалистических учений». Он требовал объявления о том, что право собственности в Российском государстве остается «священным и неприкосновенным» [6, с. 67].

Собственники небольших земельных владений также делали попытки самоорганизоваться для выражения и защиты своих интересов. На съезде мелких земельных собственников в Пермской губернии, где собрались представители 10 волостей, крестьяне-землевладельцы выступали за социалистов при выборе депутатов Учредительного собрания, 


\section{Социально-экономический и әуманитарный журнал Красноярского ГАУ. 2020. №1}

но при этом за тех, которые стояли за сохранение частной собственности на «свои» земли: «Легко расстаться с ней тому, кому легко досталась она, как, например, помещику. Крестьянину же земля досталась тяжело» $[6$, с. 69].

Однако обновленное правительство уже действовало в направлении подготовки социализации земли. По инициативе министра земледелия, лидера партии эсеров В.М. Чернова 28 июня 1917 г. было принято постановление о прекращении работ землеустроительных комиссий по реформе П.А. Столыпина, что приостанавливало закрепление в личную собственность общинной земли, в том числе в случае возможного переселения (переуступка права на землю). А.Н. Медушевский делает вывод о том, что этот акт парализовал процесс ликвидации общинного землевладения и развитие института частной собственности [1, с. 334-335]. По представлению того же министра 12 июля Временное правительство приняло постановление об актах, совершаемых по сделкам, устанавливающим вещное право на внегородские земли, занятые сельскохозяйственными и лесными угодьями. Разъяснялось, что сделки в сфере поземельных отношений, заключенные до 1 марта 1917 г., могли на законном основании подтверждаться крепостными актами, но сделки, совершенные после 1 марта, как по добровольным, так и по принудительным продажам, «кем бы они не совершались и кого бы ни касались, об установлении или переходе права собственности, залога или иного вещного права», должны рассматриваться на предмет возможного ограничения для свободы решения вопроса о земле Учредительным собранием. Ограничения объяснялись необходимостью прекращения земельной спекуляции, фиктивных сделок, махинаций с закладными бумагами, продажи земель иностранцам и др. Оборот земель до Учредительного собрания мог «в каждом отдельном случае разрешаться местными губернскими земельными комитетами, с утверждения министра земледелия». Текущие платежи по ипотечным займам переводились государству. Таким образом, происходило выведение земельной собственности из рыночной сферы, концентрации прав на распоряжение землей в руках земельных комитетов.

Обо всех земельных имуществах, назначаемых на публичные торги, должно было доводиться до сведения Министерства земледелия, которому было предоставлено право, по согласованию с местными губернскими земельными комитетами, снимать их с торгов и передавать по принадлежности во временное хозяйственное управление отделений Крестьянского поземельного и Государственного дворянского земельного барков и Управления Государственными имуществами, с переводом на государство текущих платежей процентов по ипотечным займам впредь до окончательного разрешения вопроса об этих землях Учредительным собранием [8, с. 86-87]. 


\section{История}

Юридическое совещание при Временном правительстве осторожно подходило к вопросу о праве частной собственности, огосударствления недвижимости вообще. 6 июня на заседании под председательством $\Phi . \Phi$. Кокошкина слушался проект Положения об использовании водных сил. Согласно проекту сила падения воды объявлялась государственной собственностью, использование энергии, производимой гидромеханическими установками, допускалось только на основании концессий и с разрешения правительства. Важность обсуждения этого вопроса, по мнению участников совещания, заключалась именно в вопросе «насколько проведение его в жизнь отразится на праве частной собственности» [9, с. 439]. Вопрос был поручен на детальное рассмотрение Совещания А.Я. Гальперину - известному юристу, управляющему делами Временного правительства [9, с. 439-440].

В течение лета в рамках Юридического совещания происходили дебаты по вопросу о реакции на фактические, возникавшие «в значительной части революционным путем» правоотношения в поземельной сфере. На Юридическом совещании 27 июля рассматривались «предположения» Министерства земледелия «об упорядочении земельных отношений». Возникла идея создать законопроект по узаконению новых (стихийно возникающих) земельных отношений, которые были полны «недоразумений, возникающих в связи с землепользованием, между местным сельскохозяйственным населением и владельцами, управлениями и арендаторами земель» [10, с. 107]. Юристы Временного правительства настаивали на необходимости обращаться к законодательству, иначе это может стать поводом к отрицанию любых, признаваемых действующими законами, частных прав. Приглашенный представитель Министерства земледелия Н.Е. Озерецковский, знакомый с реальной ситуацией в деревне, объяснял, что нормировка в поземельных отношениях может идти только «в порядке революционного строительства вновь сложившихся во время революции земельных отношений, которые никоим образом нельзя было бы юридически обосновать на почве всех действующих законоположений. Упоминание о сих законоположениях поставило бы деятельность земельных комитетов в тупик, и весь законопроект явился бы не достигающим почти никакой цели» [10, с. 108109].

Юридическое совещание пыталось определить хоть какой-нибудь порядок в вопросе о переходе прав владения землей и предложило ограничить срок (например, до издания закона), в течение которого «самочинные земельные отношения будут пользоваться защитой закона». Критике был подвергнут срок арендных отношений, который давал право на владение землей. Деятельность комитетов, считали юристы, должна была распространяться на земли, поступившие «фактически» в пользование местного населения в течение последних двух, трех лет. Целью земельных комитетов, согласно законопроекту, было «прекращение са- 


\section{Социально-экономический и әуманитарный журнал Красноярского ГАУ. 2020. №1}

мовольных действий в отношении землепользования» и не допущение самовольных действий впредь. Предполагалось, что после принятия «постановления» земли уже не могут «фактически поступать в пользование населения» [10, с. 110]. В проекте была высказана идея предоставления права земельным комитетам распоряжаться землями, которые комитеты признают «обработанными ненадлежащим образом», что фактически, при относительности «надлежащего уровня культурности», позволяло изъять у арендатора любой участок земли [10, с. 111-112].

В итоге были подготовлены два проекта правил об упорядочении земельных отношений от 29 июля 1917 г. [10, с. 116-119]. Они представляют интерес, поскольку отражают колебания юристов Временного правительства по вопросу о пользовании землей. Вводится понятие «целесообразное ведение хозяйства». Ответственность за необработку земли вопреки обязательству должна была устанавливаться земельным комитетом в виде денежного взыскания с необработанного участка [10, с. 119]. Земельные комитеты могли передавать земли другим пользователям на условиях арендной платы. Арендная плата в виде обязательств (отработки) и натуральные платежи могли заменяться денежными. В основу арендной платы должны были приниматься данные о чистой доходности земельных участков в данной местности, определяемой по инструкции Министерства земледелия. Государственное казначейство для передачи средств должно было образовывать депозиты.

Вопрос о возмездности при изъятии частной земли ставился авторами брошюр серии «Библиотека Учредительного собрания». Авторы одной из них считали, что в отношении земель, находящихся в частной собственности, не должна применяться конфискация. Логика аргументов строилась на необходимости сохранения права частной собственности на недвижимое имущество в целом: несправедливо изымать без оплаты у частного лица в сельской местности тысячу десятин земли стоимостью 300 тыс. руб., а у другого частного лица в городе оставлять дом, стоимостью до миллиона рублей. Значит, под угрозу конфискации попадают и находящиеся в частной собственности фабрики и денежные капиталы. Чтобы избежать кризиса собственнических отношений в целом, выдвигалось положение о необходимости получения от государства выкупа собственнической земли по оценке, устанавливаемой особыми комиссиями. Аккумулированная в собственности государства земля могла бы распределяться между земледельцами за плату в рассрочку на льготных основаниях [11, с. 18].

24 августа проект об упорядочении земельных отношений обсуждался в Юридическом совещании постатейно (участвовали Н.И. Лазаревский, А.Я. Гальперин, Б.Э. Нольде, В.А. Маклаков и Г.Э. Блосфельд). При анализе проекта указывалось, что земельные комитеты при спорах в области гражданско-правовых отношений, например по поводу договора аренды уже заключенного, должны действовать «согласно Законов 
гражданских и процессуальных». Члены Юридического совещания надеялись, что волна захватов завершится, и после издания правил земельные комитеты легализуют уже произведенные фактически захваты, а будущие «захватчики» не получат возможности обращаться к земельным комитетам. Критиковался институт посредничества земельных комитетов при заключении аренды [10, с. 179]. И все эти правила должны были иметь временный характер, а действия решений земельных комитетов ограничивались одним-двумя сельскохозяйственными сезонами.

В дополнение к Закону 12 июля 24 августа были уточнены основания, которые должны были учитывать и рассматривать земельные комитеты при решении спорных вопросов о признании права собственности. Во Временном совете Российской республики были вынесены Правила об урегулировании земельными комитетами земельных и сельскохозяйственных отношений. «Ведение земель сельскохозяйственного назначения» означало следующие обязанности и действия: учет, наблюдение, охрана, решение споров «на началах совести» с правом прекращения или изменения ранее заключенных договоров [12, д. 35, л. 36]. Приведенные положения проектов свидетельствуют о том, что юристы Временного правительства стремились сохранить систему вещных и обязательственных прав периода империи. Временное правительство намеревалось вернуть поземельные отношения в правовое поле. 7 сентября земельные комитеты были переподчинены вновь создаваемым судам по административным делам.

В протоколе заседания Контрольно-финансовой комиссии Временного совета Российской республики (Предпарламента) от 21 октября 1917 г. под председательством П. Маслова обозначены следующие правовые основания возможного признания частной собственности: купчие крепости, дарственные записи и акты пожертвования, разрядные и иные записи по приданому и выделам, акты о выкупе родовых имуществ, мировые и другие сделки, в силу которых одна из сторон уступает другой право собственности, акты об обременении имущества залогом по долгам частным лицам и кредитным учреждениям, а также сделки по передаче прав по закладным, акты об ограничении в пользу другого лица или недвижимого имущества права собственности на имущество посредством установления прав угодья, сервитутов и т. п., акты об установлении при жизни собственника права пожизненного владения другого лица, акты об установлении права застройки [12, д. 35, л. 36-37]. Эти основания показывают, что накануне октябрьского переворота в рамках Временного совета Российской республики идея титульного и документального обеспечения собственности и правил ее перехода продолжала существовать.

25 сентября Временное правительство приняло декларацию, в которой по земельному вопросу было заявлено, что Учредительное собрание объявлялось «верховным хозяином земли русской». В рамках Глав- 


\section{Социально-экономический и әуманитарный журнал Красноярского ГАУ. 2020. №1}

ного земельного комитета осенью был подготовлен проект Основного закона о земле по эсеровскому варианту. Право собственности на землю отменялось «навсегда», земля объявлялась всенародным достоянием, создавался единый земельный фонд. Право распоряжения землей принадлежало республике (органам центрального и местного самоуправления), землепользователями были все граждане России, право пользования могло быть реализовано в случае трудовой обработки земли. Право на землю оговаривалось только как право на поверхность земли (в отличие от Проекта Гражданского уложения). Закон о земле мог быть пересмотрен только в варианте пересмотра Конституции [13, с. 295-300]. Даже небольшие земельные владения и земли подворного и частного права (купчие, отрубные, укрепленные), оставляемые их бывшим собственникам, должны были проходить процедуру перераспределения [1, c. 348$]$.

Таким образом, идея частной собственности на землю, которая созревала в цивилистической мысли России и была узаконена в законодательных актах в дореволюционный период, в условиях революции сходила на нет вместе с ростом крестьянского революционного движения. Революция показала, что институт частной собственности, бывший вполне легальным, оказался нелегитимным. Попытки юристовправоведов спасти основу дореволюционных гражданско-правовых отношений через поддержку малых земельных владений, разработку системы выкупа частновладельческих земель, не дали результата. Институт частной собственности на землю прекратил существование, причем в радикальных формах конфискации и национализации.

\section{Литература}

1. Медушевский А.Н. Проекты аграрных реформ в России: XVIII - начало XXI века. М.: Наука, 2005. 639 с.

2. Гражданское уложение. Проект Высоч. Учрежд. Редакционной Комиссии по составлению Гражданского Уложения (С объяснениями, извлеченными из трудов Редакционной комиссии) / сост. А.Л. Caаmчиан; под ред. И.М. Тютрюмова. Т. 1. СПб.: Изд. книж. маг. «Законоведение», 1910. $606 \mathrm{c.}$

3. Сборник указов и постановлений Временного правительства. Вып. 1. 27 февраля - 5 мая 1917 г. Составлен Отделением Свода законов Государственной канцелярии. Пг.: Государственная типография, 1917. $557 \mathrm{c}$.

4. Революционное движение в России после свержения самодержавия / под ред. Л.С. Гапоненко. М.: Изд-во АН СССР, 1957. 857 с.

5. Сборник указов и постановлений Временного правительства. Вып. 2. 5 мая - 24 июля 1917 г. Ч. 1. Отд. I-VIII. 1918. 799 с. 
6. Дубровский C.M. Временное правительство и крестьянство // Аграрная революция. В 4 т. Т. 2. Крестьянское движение в 1917 году / под ред. и с предисл. В.П. Милютина. М.: Изд-во Коммунистической академии, 1928. $230 \mathrm{c.}$

7. Устав Всероссийского Союза земельных собственников // ГПИБР. URL: http://1917.shpl.ru/wp-content/uploads/Il302c.jpg (дата обращения: 02.02.2020).

8. Журналы заседаний Временного правительства: в 4 т. Т. 3. Июльавгуст 1917 года / сост. Е.Д. Гринько, отв. ред. Б.Ф. Додонов. М.: РОССПЭН, 2004. $416 \mathrm{c.}$

9. Архив новейшей истории России. Т. 13. Записи хода заседаний Юридического совещания при Временном правительстве. Март-октябрь 1917 года: в 2 т. Т. 1. Март - июнь 1917 года / сост. О.Н. Копылова, отв. ред. Б.Ф. Додонов. М.: Политическая энциклопедия, 2018. 599 с.

10. Архив новейшей истории России. Т. 13. Записи хода заседаний Юридического совещания при Временном правительстве. Март-октябрь 1917 года: в 2 т. Т. 2. Июль-октябрь 1917 года. М.: Политическая энциклопедия, 2019. $413 \mathrm{c.}$

11. Земля и рабочий вопрос в Учредительном собрании. Пг.: [Тип. Т-ва «Эл. Тип. Н.Я. Стойтовой»], 1917. 32 с.

12. Государственный архив Российской Федерации. Ф. 1799 (Временный совет Российской республики). Оп. 1.

13. Проект Основного закона о земле Фракции социалистовреволюционеров Учредительного собрания // Партия социалистовреволюционеров. Документы и материалы. 1900-1925 гг. В 3 т. Т. 3. Ч. 1. Февраль-октябрь 1917 г. М.: РОССПЭН, 2000. С. 295-300.

\section{Literatura}

1. Medushevskij A.N. Proekty agrarnyh reform v Rossii: XVIII - nachalo XXI veka M.: Nauka, 2005. 639 s.

2. Grazhdanskoe ulozhenie. Proekt Vysoch. Uchrezhd. Redakcionnoj Komissii po sostavleniju Grazhdanskogo Ulozhenija (S ob’jasnenijami, izvlechennymi iz trudov Redakcionnoj komissii) / sost. A.L. Saatchian; pod red. I.M. Tjutrjumova. T. 1. SPb.: Izd. knizh. mag. «Zakonovedenie», 1910. $606 \mathrm{~s}$.

3. Sbornik ukazov i postanovlenij Vremennogo pravitel'stva. Vyp. 1. 27 fevralja - 5 maja 1917 g. Sostavlen Otdeleniem Svoda zakonov Gosudarstvennoj kanceljarii. Pg.: Gosudarstvennaja tipografija, 1917. $557 \mathrm{s.}$

4. Revoljucionnoe dvizhenie v Rossii posle sverzhenija samoderzhavija / pod red. L.S. Gaponenko. M.: Izd-vo AN SSSR, 1957. 857 S.

5. Sbornik ukazov i postanovlenij Vremennogo pravitel'stva. Vyp. 2. 5 maja 24 ijulja 1917 g. Ch. 1. Otd. I-VIII. 1918. 799 c. 
6. Dubrovskij S.M. Vremennoe pravitel'stvo i krest'janstvo // Agrarnaja revoljucija. V 4 t. T. 2. Krest'janskoe dvizhenie v 1917 godu / pod red. i s predisl. V.P. Miljutina. M.: Izd-vo Kommunisticheskoj akademii, 1928. $230 \mathrm{~s}$.

7. Ustav Vserossijskogo Sojuza zemel'nyh sobstvennikov // GPIBR. URL: http://1917.shpl.ru/wp-content/uploads/Il302c.jpg (data obrashhenija: 02.02.2020).

8. Zhurnaly zasedanij Vremennogo pravitel'stva: v 4 t. T. 3. Ijul'-avgust 1917 goda / sost. E.D. Grin'ko, otv. red. B.F. Dodonov. M.: ROSSPJeN, 2004. $416 \mathrm{~s}$.

9. Arhiv novejshej istorii Rossii. T. 13. Zapisi hoda zasedanij Juridicheskogo soveshhanija pri Vremennom pravitel'stve. Mart-oktjabr' 1917 goda: v 2 t. T. 1. Mart - ijun' 1917 goda / sost. O.N. Kopylova, otv. red. B.F. Dodonov. M.: Politicheskaja jenciklopedija, 2018. $599 \mathrm{c}$.

10. Arhiv novejshej istorii Rossii. T. 13. Zapisi hoda zasedanij Juridicheskogo soveshhanija pri Vremennom pravitel'stve. Mart-oktjabr' 1917 goda: v 2 t. T. 2. Ijul'-oktjabr' 1917 goda. M.: Politicheskaja jenciklopedija, 2019. 413 c.

11. Zemlja i rabochij vopros v Uchreditel'nom sobranii. Pg.: [Tip. T-va «Jel. Tip. N.Ja. Stojtovoj»], 1917. 32 c.

12. Gosudarstvennyj arhiv Rossijskoj Federacii. F. 1799 (Vremennyj sovet Rossijskoj respubliki). Op. 1.

13. Proekt Osnovnogo zakona o zemle Frakcii socialistov-revoljucionerov Uchreditel'nogo sobranija // Partija socialistov-revoljucionerov. Dokumenty i materialy. 1900-1925 gg. V 3 t. T. 3. Ch. 1. Fevral'-oktjabr' 1917 g. M.: ROSSPJeN, 2000. S. 295-300. 